\title{
THE MINERALOGY OF XENOLITHS FROM ORAPA, BOTSWANA
}

S.R. Shee and J.J. Gurney

Introduction

The main Orapa pipe (AK1) is one of some 23 pipes in north eastern Botswana. It is $1550 \mathrm{~m} . \times 950 \mathrm{~m}$. at surface. The near-surface filling of the pipe is sedimentary (epiclastic) kimberlite which indicates that the pipe has been only slightly eroded since emplacement (Hawthorne, 1973). Serpentinized primary kimberlite is intersected in borehole cores below $90 \mathrm{~m}$ (Baldock et al, 1973). The pipe is a major diamond producer.

Small samples $\left(1 \frac{1}{2}-5 \mathrm{~cm}\right.$ longest dimension) of mantle material are recovered during the mining process. We have found abundant eclogite and garnet, clinopyroxene and ilmenite megacrysts $\left(>1 \frac{1}{2} \mathrm{~cm}\right)$ but no olivine bearing rocks (peridotites or olivine websterites).

Eclogites

Garnet and clinopyroxene are dominant in the eclogites. Variants with minor orthopyroxene, chromite, amphibole, rutile, kyanite, corundum, graphite and diamond have been found. The wide range in mineral chemistry is illustrated for the garnet compositions (Fig.1) and by the plot of the coexisting clinopyroxenes (Fig.2). In Fig. 1 there are two main trends, both starting at magnesian garnet compositions, but in the one case showing major enrichment in in iron and minor enrichment in calcium and in the second showing the reverse.

Garnets in the orthopyroxene, chromite and chrome rich eclogites have the most magnesian compositions and have the highest chrome contents for eclogite garnets at Orapa. Coexisting clinopyroxenes are calcic, have high $\mathrm{Mg} / \mathrm{Mg}+\mathrm{Fe}$ ratios and also have significant chromium and low sodium contents compared to other Orapa clinopyroxenes. Chromites have 52.1 to $57 \mathrm{wt} . \% \mathrm{Cr}_{2} \mathrm{O}_{3}$. The orthopyroxenes have $\sim 0.75 \mathrm{wt} . \% \mathrm{Al}_{2} \mathrm{O}_{3}$ and $\mathrm{Mg} / \mathrm{Mg}+\mathrm{Fe}$ at $\sim 0.93$ and are similar to enstatites in mantle garnet lherzolites.

The garnet compositions of the amphibole eclogites show a range of compositions. The amphibole which poikilitically encloses garnet and clinopyroxene may be a replacement mineral. Analysed examples have subcalcic edenite (1), edenite ( 3 ), and pargasitic hornblende (1) compositions (Leake, 1968). Kyanite and corundum bearing rocks have high grossular garnets (Fig. 1) with high $\mathrm{Na}_{2} \mathrm{O}$ contents $\left(0.07-0.17 \mathrm{wt} . \% \mathrm{Na}_{2} \mathrm{O}\right)$ and low $\mathrm{Cr}_{2} \mathrm{O}_{3} \cdot$ Corundum eclogite garnets are less iron rich than the kyanite eclogite garnets (Fig.1). The pyroxenes are diopsidic jadeites with $4.46-8.75$ wt. $\% \mathrm{Na}_{2} \mathrm{O}$ and $15-18$ wt.\% $\mathrm{Al}_{2} \mathrm{O}_{3}$ : Corundum eclogite pyroxenes tend to be more jadeitic than the kyanite eclogite pyroxenes.

Diamond has been found in four eclogites and one diamond/garnet rock. Graphite has been found in a number of eclogites including kyanite and corundum bearing types. Twelve graphite eclogites have been analysed. The garnets and pyroxenes in these rocks show wide ranges in compositions (see Figs.1 and 2). Sodium was detected in all the diamond eclogite garnets $\left(0.08-0.19\right.$ wt.\% $\left.\mathrm{Na}{ }_{2} \mathrm{O}\right)$ and in nine graphite eclogite garnets $\left(0.06-0.15\right.$ wt.\% $\left.\mathrm{Na}_{2} 0\right)$. Potassium was detected in ali the diamond eclogite clinopyroxenes $\left(0.03-0.13 \mathrm{wt} . \% \mathrm{~K}_{2} \mathrm{O}\right)$ and in five of the graphite eclogite clinopyroxenes $\left(0.05-0.17 \mathrm{wt} . \% \mathrm{~K}_{2} \mathrm{O}\right)$.

Use of the geothermometer developed by Raheim and Green $(1974)^{2}$ combined with consideration of the diamond - graphite reaction curve (Kennedy and Kennedy, 1976) suggests that the minimum temperature and pressure of equilibration ranges from $1120^{\circ}-1330^{\circ} \mathrm{C}$ and $47-53 \mathrm{~Kb}$ for the diamondiferous rocks. If graphite cannot form in the diamond stability field then the maximum equilibration conditions for graphitic rocks ranges from $910^{\circ} \mathrm{C}-1180^{\circ} \mathrm{C}$ and from 


\section{0}

42 - $49 \mathrm{~Kb}$. This implies a minimum total range of equilibration conditions of $11 \mathrm{~Kb}$ and $420^{\circ} \mathrm{C}$. Graphite, however, can possibly crystallise within the diamond stability field.

In addition to the eclogites already described there are abundant xenoliths of kyanite and almandine garnet ( $\sim 29$ wt.\% FeO); kyanite, almamine and plagioclase; and almandine and plagioclase which define a separate compositional field and are interpreted as being of deep crustal metamorphic origin.

Megacrysts

Only garnet, clinopyroxene and ilmenite have been found. The garnets which have high titanium contents, show increasing Fe/Mg with constant calcium and are similar to gamets found at Monastery Mine (Jakob, 1977) and to the low chrome megacrysts from Colorado/Wyoming (Eggler and McCallum, 1974). Sodium is detected in all megacryst garnets $\left(0.07-0.17 \mathrm{wt} . \% \mathrm{Na}_{2} 0\right)$. The clinopyroxene megacrysts fall into two groups similar to the high chrome calcic and the low chrome subcalcic megacrysts from the Colorado/ Wyoming kimberlites. Calcic clinopyroxenes have Ca/Ca+Mg ratios between 0.347 and 0.469 whilst subcalcic clinopyroxenes (2) show ratios of 0.347 and 0.363 .

Garnet Xenocrysts

Garnets $(<0.5 \mathrm{~cm})$ from the concentrate of heavy minerals obtained during diamond recovery have been analysed. A considerable proportion appear to have been derived from disaggregated eclogitic xenoliths and some appear to be fragments of the discrete garnets. The rest are low titanium chrome pyropes which do not match garnet compositions in the xenoliths or the megacrysts.

References

Baldock, J.W., Hepworh, J.V. and Marengwa, B.S. (1976). Economic Geology 71, No1, pp $139-156$

Eggler, D.H. and McCallum, M.E. (1973). Carnegie Inst. Yearbook 73 pp 294300

Hawthorne, J.B., (1973). Physics and chemistry of the Earth Vol.9

(Pergamon Press) pp 1 - 15

Jakob, R (1977) MSc. Thesis. Geochemistry Dept. University of Cape Town.

Kennedy, C.S. and Kennedy, G.C. (1976) Jour. Geophys. Res. 81, No 14, pp2467 - 2470

Leake, B.E. (1968) Geol. Soc. America Spec. Paper 98 210p

Raheim, A and Green, D.H. (1974) Contrib. Min. and Pet. $\underline{48}$, pp $179-283$ 


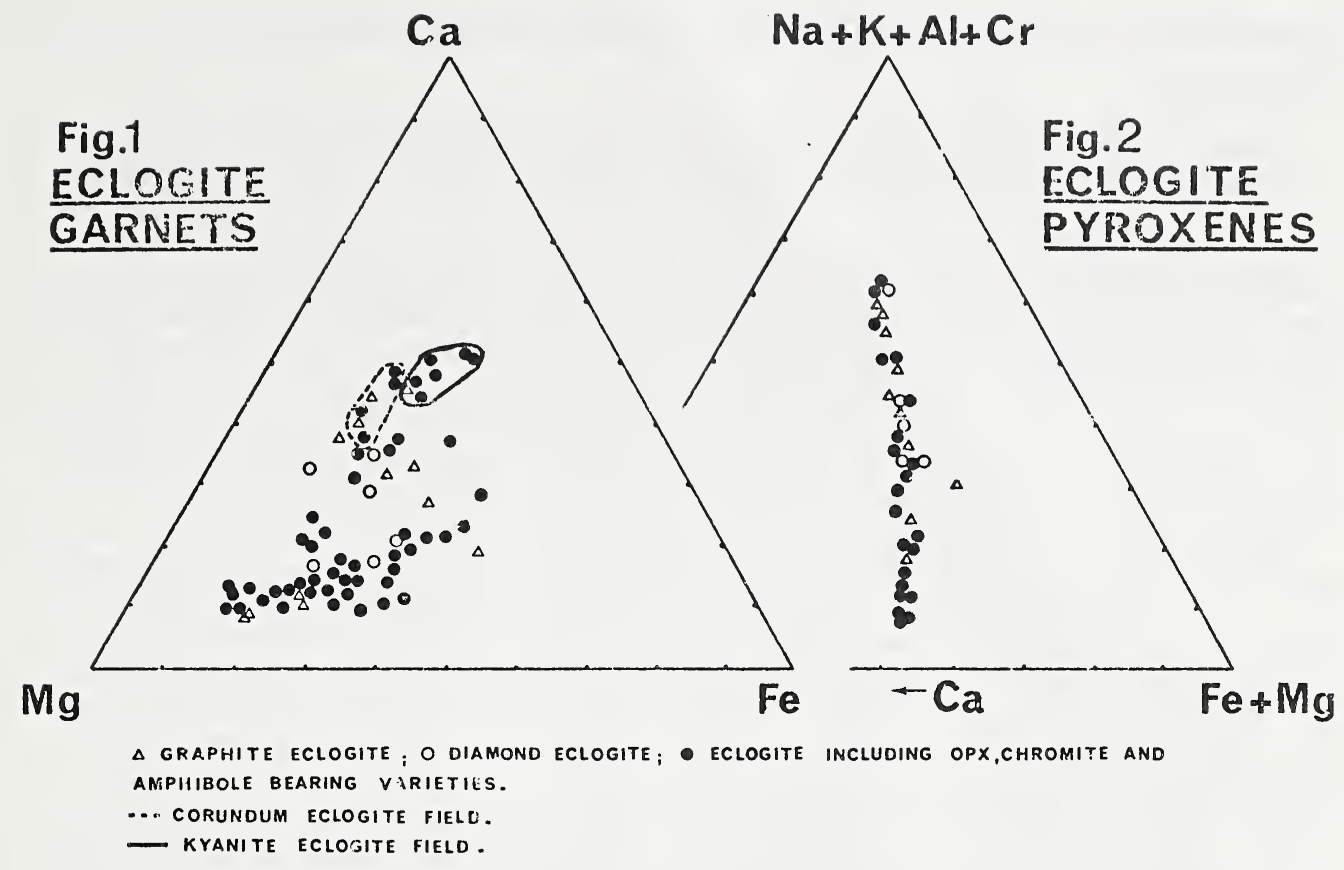

Fig.1 Atomic proportions of $\mathrm{Ca}, \mathrm{Mg}$, Fe for analysed eclogite garnets from Orapa.

Fig.2 Atomic proportions of $\mathrm{Na}+\mathrm{K}+\mathrm{Al}+\mathrm{Cr}, \mathrm{Ca}, \mathrm{Fe}+\mathrm{Mg}$ for eclogite clinopyroxenes from Orapa. 